\title{
E-Marketing Model For Successful Entrepreneurs
}

\author{
Hafiz Sabih Ahmad \\ National College of Business Administration \& Economics \\ Lahore Campus Pakistan \\ Syed Muhammad Taha \\ National College of Business Administration \& Economics \\ Lahore Campus Pakistan \\ Dr. Fareeha Zafar \\ Department of Computer Science \\ Government College University, Lahore. Pakistan
}

\begin{abstract}
This paper illustrates a new electronic model for successful entrepreneurs. The authors have analyzed classical models namely 5ls Model, 10 C's of Marketing, 3-Race Planning, 4 C's marketing model \& McKinsey's consumer decision journey, and have found certain inadequacy to fulfill the need of digital era in view of which the proposed model includes certain Tools, a Tranquil design, Contingency, Commitment level and feedback. This eventually helps in optimum utilization of electronic marketing tools. The proposed model is equally beneficial for Small scale and large scale businesses in order to gain visible growth and development which ultimately affect the economy of the state or country. This model helps entrepreneurs to flourish their business in a quick and enhanced way. The new design is comprehensive and brief; it fulfills the requirement of all types of trades which is comprehended in the paper.
\end{abstract}

Keywords: Marketing model, E-Marketing model, Entrepreneurs, Successful entrepreneurs

\section{INTRODUCTION}

Entrepreneurship is the creation of something new. Entrepreneur is a person who thinks or sees something different from others who generate different ideas, business promotions, and new techniques to enter in a market. His ideas must be different which helps to increase the efficiency and effectiveness of business. Entrepreneur always looks at the all perspectives of business which includes loyalty of employees, motivation of employees, low employees turnover, effective marketing, innovations, optimum use of resources, foresighted, decision making, and effective policies for achieving goals. Entrepreneur must be have leadership qualities because business can't be run by one person, business needs different teams to work efficiently so if entrepreneur in not a leader he can't lead his employees and don't work according to his thoughts or passion.Entrepreneurship takes place and has effects on different social levels simultaneously.

E-marketing is a modern tool to promote someone. In the current era the most effective and efficient tool for promoting business is e-marketing. E-marketing means using social media, web site, blogs, ad words, search engines. Now a day's people are so much busy so they have no time to visit markets or shopping malls. They feel comfort if they get everything in their homes or offices. E-marketing is used to develop personal interactions between employees and customers which help to retain their customers. 
E-Marketing making revolution in the business practices. Some minds said that these changes lead business to the next level. From 1990s boom comes in IT which have potential impact for all fields. IT helps to improve or enhance new tactics of marketing. There are some studies who talk about different features of E-Marketing and E-Business.

We develop a framework which differentiates between four different aspects of marketing practice.

Traditional Marketing: It is an approach in which we use "4Ps" model to attract our customer in a broad market. e.g., Product, Price, Place and Promotion these four tools are used to create charm for new customers.

Database Marketing: It is an approach in which business uses its database of its customers to target and attract by using external marketing activities. This approach is used for a specific or a particular segment of the market.

Interaction Marketing: This approach is used in services business in which face-to-face interactions is the base of marketing. You have to develop personal relationships with your customers and employees.

E-Marketing: It is an approach in which we use internet and other tactics or modern technologies to build a relationship between the firm and customers. By using Internet-based system business attracts their customers, clients or patients. By using electronic tools we provide access to customers about the information of business.

\section{LITERATURE REVIEW}

Individuals who take initiatives for something new in the market are known as Entrepreneurs. Innovations which we see in this era are the initiatives of entrepreneurs. (Schumpeter, 1934)

This study says that, due to the increasing trend of entrepreneurship there is an increase in employment which ultimately affects the per capita income of the country which shows the economic growth of the country. (Baumol, 1990)

Business performances have significant relationship with market orientation and marketing. There is as positive effect on business performances of these variables. (Deshpande $R, 1993$ )

This study explores that the element of risk is high and have more chances of low performance if there is absence of market orientation. Market orientation is one of the basic elements which contribute a major part in the success of business. (Schumpeter, 1934)

Economic development of a country depends on the entrepreneurial initiatives which also linked to the creation and destruction of industries. Setup of new firms is due to the entrepreneurial initiatives. (Moran, 1999)

This research explains the positive impact of entrepreneurial activity for the performance of a company. Firm survival, technological change, innovation, productivity, employment creation, increase in import and export are some elements which effects due to the entrepreneurship. (Dusan Baran, 2008)

Search engine optimization is one tool of e-marketing. This study shows the importance of SEM for medium or large enterprises. Most firms use SEM strategy to attract or control traffic of 
customers. For utilizing SEM you have to pay fee named as "Pay for Placement" which helps you to show your business cite. Higher pay, high ranking in SEM. (Barry, 2009)

This study argued the revolution in marketing. Three types of changes identified, Marketing management change, cultural change and marketing in new medium which is internet marketing. The need is to recognize the challenges and use these changes. (Rettie, 2003)

Small business operations facing problems in maintaining customer service, public relations and most importantly brand building by the use of internet marketing. This study also shows that new business is more focused on these tools as compared to established businesses which are the reason of success of entrepreneurs. (Ateer, Adelle Mc, 2010)

\section{METHODOLOGY}

In this paper during research we utilize secondary data, we took 5 famous e-marketing model, critically analyzed and present a new model which brief and comprehensive for all types of businesses.

\section{5ls Model}

\section{EXISTING MODELS OF E-MARKETING}

\section{Involvement}

Primarily, customer is attached with brand \& application, the participation of customers can be verified through tools like site traffic, time spent and page views etc. Customer is involved or not, these tools will let you know.

\section{Interaction}

After involvement customers will disclose its interest by buying a product by signing up in application. Often customers will ask for price catalogue. Usually customers write comments or blog to express their condition.

\section{Intimacy}

Customers usually state their sentiment by saying, taking an action, meaning behind a blog, comment, post or product review. Loyal customers are the only way to measure Intimacy.

\section{Influence}

When a customer has a good experience than customer will share his feelings with others. Good experience allows the customer to become loyal with brand and refer others to enjoy such product or service.

\section{Individual}

This model specially designed for individuals rather than communities \& clusters.

\section{Criticism}

In this model, element of feedback is completely missing. Mostly businesses flourish with the help of opinion of their customers. But in model such concept is completely not available. An emarketing model should include feedback by customer which will play vital role in the betterment of one's conern.

\section{C'S OF MARKETING}

Marketing models are useful outlines to focus planning and strong mechanisms to let the organization develop marketing plans. Some models are relevant for the new age of Digital 
Marketing like $10 \mathrm{C}$ 's of modern e-marketing. Chartered Institute of Marketing examiner Richard Gay designed this model especially for digital marketing and featured in online marketing, it was originally published in 2007.All possible elements of an online marketing framework are considered in 10 C's. This could be interior and can be used to review website of an organization and related marketing communications and how it is managed or it can be used to audit competitors' activities as an external tool. The customer is positioned in the centre and every element is reviewed to explore how well it completes the need of customer. Following diagram is self-explanatory;
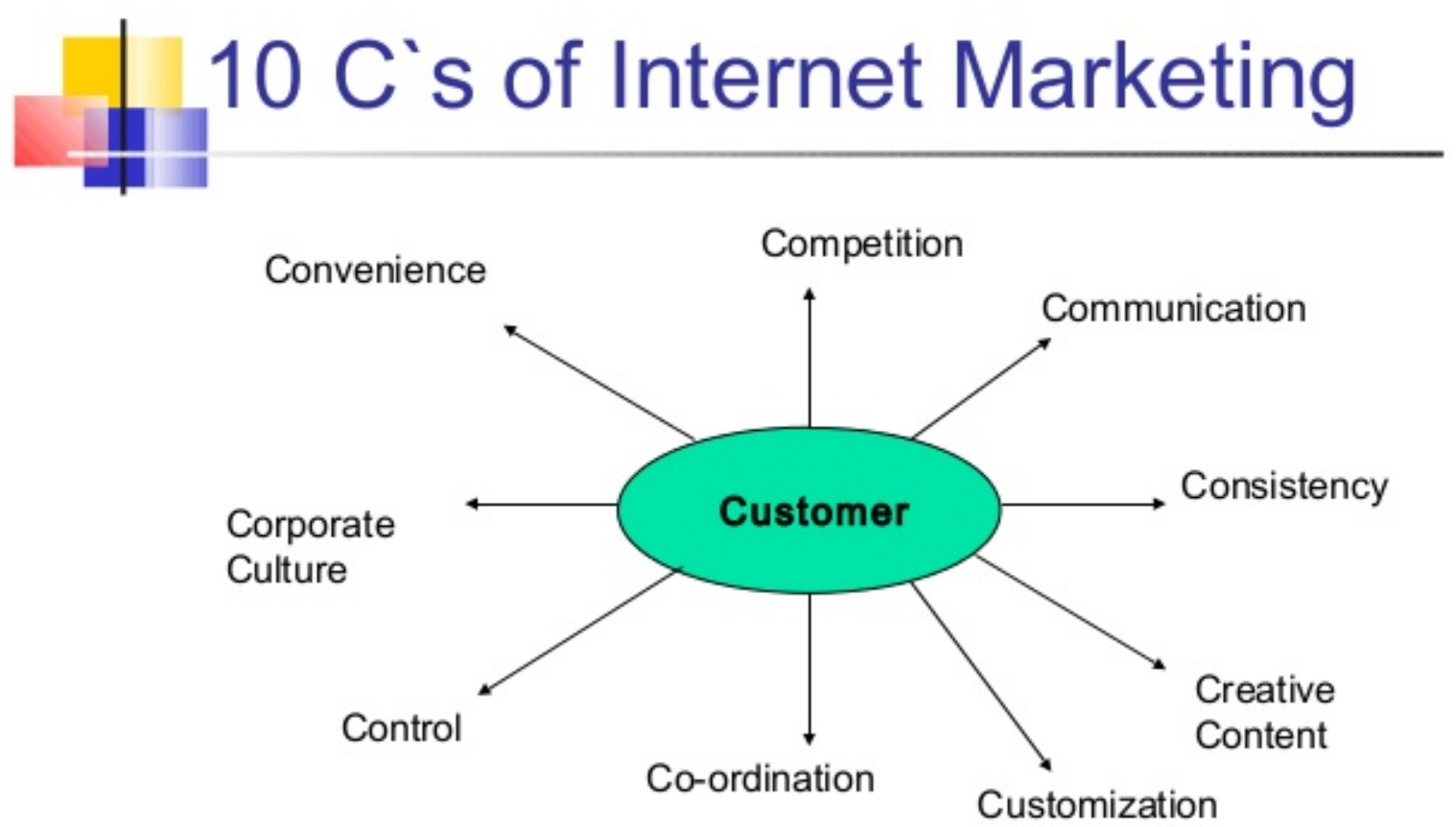

\section{Figure: 10C's Internet Marketing Criticism}

This model is although look perfect but model looks complex. E-marketing model should be simple and brief though customer will enjoy maximum benefit. If customer finds your marketing model complex and hard to understand than it means you lose your customer. This model is quiet tough for a new customer to understand.

\section{3-RACE PLANNING}

One should be familiar with RACETM planning which is developed system by Smart Insights to help marketers to ripen digital marketing plans which are focused on sales growth. It is a popular digital marketing model.

\section{Criticism}

This model is famous among business concerns because it is focused on sales growth directly but it is failed to explain the tools which one should use. They didn't tell regarding feedback of customers. If your sales growth is enjoying high position but your feedback is zero than there are some flaws which should be addressed. 


\section{C'S MARKETING MODEL}

There are two groups of marketers who created the 4Cs. This often take you to confusion about what is being discussed and where?

Let's elucidate the two models:

"The 4Cs to replace the 4Ps of the marketing mix: Consumer wants and needs; Cost to satisfy; Convenience to buy and Communication (Lauterborn, 1990)"

"The 4Cs for marketing communications: Clarity; Credibility; Consistency and Competitiveness (Jobber and Fahy, 2009)"

Figure: 4C's Marketing Model

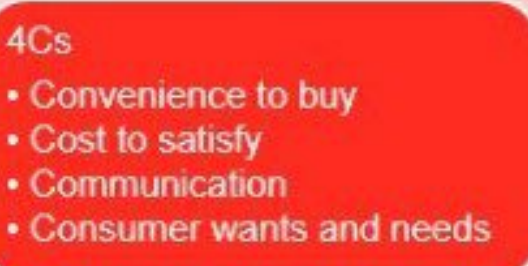

$4 \mathrm{Cs}$

- Convenience to buy

- Cost to satisfy

- Communication

- Consumer wants and needs

\section{Criticism}

\section{$4 \mathrm{Cs}$}

- Consistency

- Clarity

- Competitiveness

- Credibility

This model is quiet impressive but it didn't tell regarding marketing tools. All tools can't be used for all businesses. Complete e-marketing model is that which defines the tools which will be used during marketing. Model should be simple to understand as well.

\section{MCKINSEY'S CONSUMER DECISION JOURNEY}

In 2009, McKinsey with his company suggested a dramatic substitute to the traditional purchase funnel. After making 20,000 interviews with businesses in the USA, Japan \& Germany, their research came into being.

Model consists on following;

$$
\begin{aligned}
& \text { Align - be part of the initial consideration } \\
& \text { Link - integrate all aspects of the brand } \\
& \text { Lock - Find ways to retain customers' interest } \\
& \text { Loop - Explore ways to build advocacy }
\end{aligned}
$$

\section{Criticism}

E-marketing design should be simple and brief which everyone can easily understand what is going to communicate. Tools should be defined which are going to use in the model. If design is complex and tools are not mentioned than it will not be a perfect e-marketing model. 


\section{PROPOSED MODEL}

After critical analysis of classical e-marketing models, some flaws are identified \& it became necessary to put a proposed model to fulfill the gap. Content of proposed model is as follow;

\section{Tools}

All tools can't be used for all types of businesses. Which tool will be remained attractive and efficient for particular business is primarily decided. E-marketing is vast concept that's why first of all Tools for entrepreneur are defined which will measure how business can be converted in brand with limited resources.

\section{Tranquil design}

The content which is provided to customers should be in simple form which should easily understandable for customers. Because we are talking of entrepreneurs who have limited customers, if customers find complex content during searching regarding brand, customer will remain unable to understand the true characteristics of product which will cause loss of customer.

\section{Be contingent}

People need change always. Entrepreneurs can't be consistent on same style of marketing. Marketing style should be altered as per the desires of customers. Entrepreneurs will remain successful if they change their marketing plans according to the trend. If customer wants to be emailed than email, if customer needs all information on website than do as per his claim, if trend of marketing on social media is popular than entrepreneurs should utilize that concept, if customer wants information on text at cell phone than do it. Entrepreneurs should flow in the stream of desire of customer.

\section{Commitment Level}

At this stage, commitment level of customers is tartan. If customer is unduly paying visit to your website it clearly means that customer is interested in your products. He will be proven loyal if he remain attach with your business and urges others to join your products. If an entrepreneur loses their regular customer than it is necessary to bring him back by generating automatic e-mail or any other contact.

\section{Feed Back}

Entrepreneurs should urge their customers to give feedback by writing online blogs, comments and email because feedback plays vital role in the progress of any business.

\section{CONCLUSION}

It is concluded that classical models have some flaws and gaps to cover all aspects of emarketing. Now the trend is SME's are also using internet marketing so it should be simple and easy to understand but unfortunately the existing models didn't complete these requirements. We proposed new model for E-Marketing for all business which is simple to understand, easy to apply and affordable for all. By using this new model business grow rapidly which ultimately effects the economic situation of Pakistan.

\section{References}

Ateer, Adelle Mc. (2010). Marketing in SME's during economic crises: an investigation of marketing activities with in the small retail sector. letterkenny Institute of Technology.

Barry, C. C. (2009). In Search of Search Engine Marketing Strategy Amongst SME's in Ireland. ARAN-Access to Research at NUI Galway. 
Baumol, W. (1990). Entrepreneurship: Productive, unproductive and destructive. Journal of the political economy, 893-921.

Deshpande R, F. J. (1993). corporate culture, customer orientatin, and innovativeness in Japanese firms. Journal of Marketing, 23-27.

Dusan Baran, r. v. (2008). Building the theoretical framework of entrepreneurship. 5th Internatinoal Scientific Conference Business and Management 2008. Vilnius, Lithuania.

Moran, P. \&. (1999). Markets, firms, and the process of economic development. Academy of Management Review, 390-412.

Rettie, R. (2003). How the internet is changing traditional marketing. Kingston Business School.

Schumpeter, J. (1934). The Theory of Economic Development. Cambridge: MA: Harvard University Press. 